\title{
Is the Control of Conventionality Really Viable?
}

\author{
Max Silva Abbott* \\ University of San Sebastian
}

The theoretical way in which the majority doctrine addresses the control of conventionality could be significantly modified if one takes into account the real level of compliance with the judgments in which the Inter-American Court has ordered to carry out. The present work analyzes this data, almost always omitted, and incorporates it into the doctrine of conventionality control, to try to determine if such control is viable in practice. This, given the leading role assigned to the Court for the proper functioning of this control.

Keywords: control of conventionality, compliance with the judgments of the inter-american court, monitoring compliance, inter partes effect, erga omnes effect

\section{INTRODUCTION}

There is currently what could be called an 'official' approach to the theory of conventionality control, which is driven both by the jurisprudence of the Inter-American Court and by the majority doctrine, which has been widely disseminated. However, the present work investigates a fact that has generally been omitted in this respect: the real level of compliance with the judgments that establish such control, several of which are paradigmatic at the time of their foundation. Therefore, it is legitimate to ask, on the one hand, if the way of approaching the control of conventionality would be different if this information were taken into account and, on the other hand, and as a consequence of the above, to what extent it is viable, given the leading role assigned to the Court for its proper functioning.

In an attempt to answer these questions, we will first briefly and without controversy review the current theoretical state of conventionality control as presented by the majority doctrine. Although the above is generally well known, it is essential to bring it up, in order to have clarity about the real implications that the mentioned level of compliance has for such theory. The methodology used for the analysis and classification of the effectiveness of the sentences in which the Court has ordered this control will be explained later, and the data is included in annexes I and II of this work. These data will be subsequently shown in graphs and some brief comments will be made on them. Later, and on the basis of the above theoretical description, the doctrine of control of conventionality will be reconsidered, incorporating this new information and, as has been said, an attempt will be made to determine whether such control is viable. Finally, some conclusions will be drawn. 


\section{THE MOST RELEVANT ASPECTS OF THE DOCTRINE OF THE CONTROL OF CONVENTIONALITY}

In this section, the main statements made by the jurisprudence of the Inter-American Court and the dominant doctrine on the control of conventionality will be presented, without delving into them, while also taking an uncritical look at them and presenting them in a hypothetical manner (that is, with all the consequences assigned to them), in order to make clear both their theoretical scope and the role that this court is given for their correct application. The above, in order to have a clear point of reference to which the practical information analyzed in this paper can be added later.

As we know, the control of conventionality is not contemplated in the American Convention ${ }^{1}$, but has been developed through jurisprudence, being established for the first time in the case of ALMONACID ARELLANO ET AL. V. CHILE ${ }^{2}$.

However, a distinction is usually made between an external control of conventionality, which is carried out by the Court ${ }^{3}$, and an internal control, which is what local judges would be called upon to do ${ }^{4}$.

The control of conventionality has experienced a constant expansion ${ }^{5}$, although its jurisprudential development has not always been linear or organic ${ }^{6}$. Thus, after establishing it in the ALMONACID case, the Court considered that it should be performed by the judges of the judiciary ex officio and "evidently within the framework of their respective competences and the corresponding procedural regulations" added the constitutional courts ${ }^{8}$; then it was the turn of all local authorities, including the Executive and Legislative branches ${ }^{9}$, and finally it was applied to democratic bodies as well ${ }^{10}$. That is why it was pointed out at the time that the control of conventionality was a kind of "ray of destruction of local norms"11. Here we will deal fundamentally with the one which domestic judges are called upon to carry out.

Furthermore, it should be kept in mind that the reference point for carrying this out is the so-called "controlling normative material", which includes both the American Convention and the other treaties of the Inter-American System, as well as the jurisprudence of the Court in this regard. ${ }^{12}$.

Now, returning to the control that internal judges are urged to carry out, it has been said that they should first attempt a harmonization between both normative orders" (which is also called "conforming interpretation") and only in the event of being incompatible, would they be bound to leave aside or not apply the local regulations ${ }^{14}$, even if they are of constitutional rank, in pursuit of the international provision.

In case of not eliminating the unconventionality, the country would fall into international responsibility ${ }^{15}$, since it is considered that it continues as long as the incompatible rule remains ${ }^{16}$.

Nevertheless, there is an exception to this possibility, in the event that the domestic provisions are more favorable than the international ones, by virtue of the pro homine principle, which requires that the regulations that most protect or least restrict the rights in question be sought ${ }^{17}$.

Therefore, although there are many definitions and ways to explain it, we could say that the control of conventionality is the comparison that the Inter-American Court makes by itself and that it also orders national judges to make, between the American Convention and the other human rights treaties of the InterAmerican system that grant it competence, as interpreted by it, and the internal rules of each country, in order to make international provisions prevail over national ones, except if, from its perspective, the latter protect human rights better than the former, by virtue of the pro homine principle.

However, the jurisprudential development of the control of conventionality has gone further. In fact, since the Court is considered to be the definitive ${ }^{18}$ and unappealable ${ }^{19}$ interpreter of the Convention, in essence this treaty only 'speaks' through it. That is why it considers that every interpretation it makes of it updates it and would automatically be incorporated into it. And since the countries signed this treaty in sovereignty, they would all be bound by this interpretation, even if they were not part of the dispute that gave rise to it. Therefore, the reasoning developed by the Court in each cause (the so-called res interpreata) would bind all States, thus having an erga omnes effect ${ }^{20}$. Consequently, national judges should use the control of conventionality inspired by any judgment or Advisory Opinion issued by the Court "for all the hypotheses in which its application is relevant" ${ }^{21}$. and not only in the causes that have affected their country $^{22}$. 
In this way, the idea is that domestic judges become the first guardians of the Convention ${ }^{23}$ (some even call them "inter-American judges" ${ }^{" 24}$ ), in order to give real effectiveness to International Human Rights Law in our region and allow the State to be the first to resolve possible violations of it, so that the role of the Court is truly subsidiary ${ }^{25}$.

Consequently, the Court intends to achieve a multiplying effect ${ }^{26}$ of its judgments throughout the continent, in order to prevent many disputes from coming to its attention ${ }^{27}$, to give unity to our regional human rights system ${ }^{28}$ and thus to achieve an "inter-American public order" 29 or an "inter-American ius commune" ${ }^{30}$. Or, alternatively, it seeks to become a kind of continental constitutional or cassation court ${ }^{31}$ that establishes through its jurisprudence a system of binding precedents ${ }^{32}$.

This last point is very important, since, as will be mentioned on more than one occasion, it is not enough for local courts to apply the control of conventionality: they must do so according to the criteria established by the Court, which would always have the last word on its appropriateness ${ }^{33}$.

Now, as these local judges are the first guardians of the Convention, their role in the protection of human rights should go further. Thus, for example, Professor Nogueira ${ }^{34}$ urges them to also apply "the methods of interpretation developed by the IACHR: the evolutionary, dynamic and finalist interpretation; the use of basic principles of interpretation of rights: 'pro homine' or 'in favor of the person', progressiveness, proportionality, to name but a few, those which constitute a source of extension of their jurisdictional power..."35.

Furthermore, this requirement to interpret local law in the light of international law should be applied prior to any other way of trying to unravel its meaning and scope by the judge, who must make "adaptive re-readings of national law, of a harmonizing type, in accordance, that is, 'in conformity' with the Pact and such jurisprudence. [...] Strictly speaking, the local judge would have to begin his analysis of the national norm on the basis of the Pact of San José and the aforementioned case law, before beginning to understand it with national legal inputs" ${ }^{\prime 36}$.

However, it should be noted that all this "implies thinking, interpreting and making all domestic law work, in conformity with the guidelines of the Pact of San José, Costa Rica, and the jurisprudence of the Inter-American Court of Human Rights"37.

The above, unless, as has been said, by using the pro homine principle, domestic regulations are used, as they are considered more protective and suitable than international ones.

That is why it has been repeatedly pointed out that international human rights law only establishes the "minimum standard" 38 in the protection of these rights. Hence, there is nothing to prevent countries from establishing more protective regulations in this respect, or from restricting them to a lesser extent in cases where it is legitimate to do so. Consequently, by virtue of the pro homine principle, the local judge would be compelled to seek the most beneficial regulation, whether national or international ${ }^{39}$.

It has even been argued that the pro homine principle would make the rules of hierarchy within legal systems obsolete. In other words, the hierarchical criterion would give way to that of greater protection, and this better protection could be found in both domestic and foreign regulations ${ }^{40}$. However, this determination will depend, at least in the first instance for these 'Inter-American judges', on the circumstances of each case, and it is impossible to determine it a priori, even partially ${ }^{41}$.

All in all -and very importantly for this study-, it should be noted that the Inter-American Court would always have the last word, since, as has been said, in the event that the cause comes to its attention after all domestic avenues have been exhausted, it is not enough for the defendant State to point out that the local judge exercised control of conventionality, since in theory, the international court could always correct its application. In other words, rather than carrying out the control of conventionality, the Court requires that it be used correctly ${ }^{42}$.

In this way, an "interjurisdictional dialogue" would be formed between national and international judges, which would generate mutual enrichment and ultimately better protection of human rights in the inter-American system ${ }^{43}$.

In this same sense, given that the pro homine principle forces the judge to seek the most favorable regulations, Professor Nogueira has also pointed out that by virtue of the above, local judges could improve the standards reached by the Court not only by applying local regulations if they are more favorable, as has 
been said, but also by extending the interpretation of international instruments already made by that court, thus going further or even opening new and original paths in matters on which it has not yet ruled. Nevertheless, as in the previous cases, the Inter-American Court would always have the last word, if the case came to its attention, because basically, no matter how much freedom and innovation the pro homine principle seeks to achieve, in theory nothing can go against what this international court considers correct ${ }^{44}$, since the idea is to arrive at a ius commune or an inter-American public order.

Thus, among other possibilities raised by this author, there could be:

a) An extensive interpretation, in which by means of his own exegesis, the national judge could go beyond what is established by the Court in the protection of a particular right. These national decisions could eventually influence the Court, although its verdict would have to be awaited, by which the Court would be free to approve or disapprove such an interpretation, thus being a potential dialogue ${ }^{45}$; or

b) An innovative interpretation, which is one that addresses rights not previously analyzed by the Court, when there is silence on its part. This would create an unprecedented jurisprudential solution, in which the local judge "can free himself from the servitude of national law"46, having the power to grant greater scope, lessen restrictions, give new focus to the rights involved and also to censure the national norm. This generates a "bottom-up dialogue, which is suspended until the IACHR, hearing an analogous case, confirms or reverses the decision made by the national judge" ${ }^{\prime 4}$. In this way, "The national judge must proceed with this innovation, studying inter-American jurisprudence to predict what the solution developed by the inter-American judge will be in unpublished disputes. If the national judge acts otherwise, he risks subsequent condemnation by the IACHR"48.

Therefore, if everything said so far regarding the application of the control of conventionality and the pro homine principle is connected, in theory the internal judge could:

a) Disregard the national rule in favor of the international one (whatever this means, which cannot be analyzed here);

b) Make a harmonizing interpretation of the local rule with the international one, which, by the way, could significantly alter its meaning and scope;

c) Give priority to the local rule, if in the judge's view it is more favorable;

d) Conduct an extensive interpretation of the international rule, which could in turn give rise to possibilities $a$ ) or $b)^{49}$; and finally,

e) Provide an innovative interpretation of the international rule, with the same two possibilities outlined in the previous letter.

It is stressed that the Court should always have the last word in these situations, to avoid its designs being 'betrayed' through their use, as it is considered the official interpreter of the Convention ${ }^{50}$. This means that if the local authorities do not apply the control of conventionality or do so defectively, there would be international responsibility for the State and it could be sued before it ${ }^{51}$. In other words, it is not enough for the local judge to claim to have exercised internal control, as the Court is not precluded from applying its own - external- control of conventionality ${ }^{52}$.

These are the main postulates of the theory of control of conventionality defended by the majority doctrine, which will serve as a reference point for us to compare this approach with the real level of effectiveness that the sentences in which the Court orders it to be carried out have had. Below we will point out some methodological aspects that have been used to carry out this work and to determine the degree of compliance with the sentences in which the Court orders this control, and which explain the structure of annexes I and II of this document.

\section{METHODOLOGICAL ELEMENTS TO BE TAKEN INTO ACCOUNT}

As mentioned above, this study analyzes the effectiveness of the judgments in which the InterAmerican Court has ordered the control of conventionality. There are three reasons for limiting this analysis to these rulings alone. 
The first is for reasons of volume: the single annex with all the Court's judgments and their current status would take up more pages than this work.

The second is due to the theoretical importance of these resolutions: being a praetorian creation ${ }^{53}$, the eventual normative force of the control of conventionality comes only from the judgments that consecrate it (and from the Advisory Opinions that establish $\mathrm{it}^{54}$, a subject that is not analyzed here). Moreover, the Court has been expanding its scope in this same way. That is why it is absolutely necessary to analyze the level of compliance with these judgments.

Finally and thirdly, because if the Court intends that the control of conventionality has erga omnes effects, it seems logical that it be applied first by the States condemned by the sentences that establish it (by virtue of its inter partes effect, according to art. 68.1 of the Convention), since in our opinion, this obligation is more peremptory -and therefore its most serious noncompliance- in these cases, the only ones in which, in addition, the Court can follow its evolution through compliance supervisions.

All this explains, then, our special interest in these particular rulings.

Finally, it should be noted that in order to ascertain the degree of compliance with these rules, the reasons that may have existed in each country -which would exceed the limits of this study- have not been analyzed, but only the data provided by the Court itself on its website ${ }^{55}$. What is important for these purposes is that, independently of the cause, we have objective data: the real level of compliance with the rulings that establish the control of conventionality, an aspect that in our opinion should be taken into account when dealing with its theory.

To determine the level of compliance, a general survey was first made of the judgments of the contentious cases issued by this court. According to the information on its website, as of December 31, $2017^{56}$, the Court had issued a total of 344 rulings. However, this does not mean that the same number of cases have been decided, as there are several cases with more than one ruling. This is because in addition to Judgements on Merits, there are Preliminary Objections, Reparations and Costs, Compliance with Judgment and Interpretation of Judgments from all of them. Hence, the real number of cases is actually 227.

Of these 227 Judgements on Merits, the Court refers to the control of conventionality in 42 of them ${ }^{57}$, although references to each other and repetitions are very abundant. Also within these same cases, this subject is mentioned in 3 Interpretation of Judgments ${ }^{58}$ and in 14 Monitoring Compliance (hereinafter, M.C. $)^{59}$. All this information is included in Annex I of this paper.

However, since references to the control of conventionality do not appear only in the Judgments on Merits, this led us to investigate whether the Court was alluding to it in other cases. This is how we discovered that in addition to the 42 cases just mentioned, it does so in 26 more cases, not in its Judgments on Merits, but in 38 M.C., and in one Provisional Measures (hereinafter, P.M.). This information appears in Annex II of this study.

Thus, until the end of 2017, the Court has actually expressly addressed the issue of control of conventionality in 68 cases, broken down into 42 Judgements on Merits, 3 Interpretation of Judgments, 52 M.C. and 1 P.M. In each case, the paragraph or paragraphs referring to the control of conventionality are indicated. Finally, it should be noted that with respect to the M.C., they have been counted not according to the number of resolutions of this type that have been issued, but according to the number of cases to which they allude, since it is frequent that they refer to more than one case, although always referring to the same country.

Both annexes also indicate the current status of each case, always according to the information provided by the Court's website (in the link "Orders on the Monitoring Compliance with Judgment" ${ }^{\prime 60}$ ) and the M.C. of each one of them, if any, referring to their fundamental paragraphs at the bottom of the page for each case.

This way, the current status of the cases can give 4 results: Full Compliance, Partial Compliance, Unfulfilled and Pending.

In order to distinguish between these four possibilities, however, a distinction was made, according to their nature, between the different obligations that the Court requires of States. Consequently, these obligations can be grouped as follows: $a$ ) Payment of compensation in general; $b$ ) Payment of costs and 
other expenses; c) Obligation to investigate and eventually punish those responsible for the violations found, including the search for possible remains of the victims, if any; $d$ ) Carrying out the legal modifications ordered by the judgment; $e$ ) Carrying out various measures of reparation (public act of recognition of international responsibility, publication of extracts of the judgment in a local newspaper, construction of monuments, change of names of public places, etc.) and $f$ ) Other measures (medical and/or psychological care, scholarships, etc.)

Clearly, the fulfilment of these obligations has a widely varying level of difficulty. For example, it is much more complex to make legal changes than to publish an extract of a judgement. This explains why they have not been simply quantified globally without distinguishing between them, as this could lead to confusion. This is why obligations (a), (c) and (d) have been considered the fundamental ones, and it is around their degree of compliance that the above-mentioned classification is made, despite the fact that when comparing them with each other, it is also much easier to pay compensation than to make legal modifications or investigate the facts.

Thus, cases with Full Compliance are those in which the Court has indicated by means of an M.C. that the State has satisfied all the obligations imposed in the Judgment on Merits, thus ordering the case to be filed, and furthermore, they appear in the section "Cases Filed by the Monitoring Compliance with Judgment (Only in Spanish)" ${ }^{31}$.

Cases with Partial Compliance are those in which the State has only partially satisfied its obligations, for example, if it has paid the compensation or most of it, even if the corresponding investigations have not been initiated or only partially and/or if the legal modifications indicated by the Court have not been introduced, even though, as has been said, the first is much easier than the latter two measures. In other words, the payment of compensation, or at least most of it, has been considered here as Partial Compliance, which is why, in the present study, the threshold for estimating that a case falls within this classification has been quite low. Otherwise, several other cases would have been classified in the following group.

Unfulfilled judgments are those in which the above has not occurred, or the level of compliance is minimal (for example, only the judgment has been published in a local newspaper or a public act of reparation, but no compensation has been paid to the victims and the alleged perpetrators have not been prosecuted, nor have legal changes been made).

Finally, the Pending cases are new cases, which do not have any M.C. or P.M. after the Judgment on Merits have been decided, although the latter may have been decided before the ruling. Likewise, the official information of the aforesaid link "Orders on the Monitoring Compliance with Judgment" has been taken into account. As they do not have a M.C., there is no information about them at the foot of the page either. However, it is important to emphasize that they are either Unfulfilled or Partially Compliant because if they had Full Compliance, the Court would have already made a record of it-, although it is not possible to determine in which of the two states, according to the information gathered for this study. However, whether they are in one or the other situation has not greatly influenced the results of this study.

It should be noted that for these Pending cases, there are other data that give clues about their state of progress, such as videos of hearings ${ }^{62}$ or "press releases" $"$. However, we have not considered the information contained therein until it is officially recorded in a resolution of the Court itself.

It is now time to make some reflections on the level of compliance achieved in the cases in which the Inter-American Court has ordered the application of conventionality control, information that is included in Annexes I and II of this work.

\section{SOME CONSIDERATIONS ON THE BASIS OF THE DATA OBTAINED}

The fundamental aspect that stands out from the information provided in Annexes I and II, is the notable level of ineffectiveness presented by the cases in which the Inter-American Court has ordered the application of conventionality control, which shows a great resistance of States to follow its rulings. It should be taken into account that in this study, the criteria to determine whether a case has Partial Compliance is quite low, since it is much easier to pay compensation or even part of it than to make the legal modifications or judicial investigations ordered by the Court. 
In addition, this low level of compliance generates no less procedural wear for this court, as it is forced to issue numerous annexed resolutions (requests for interpretation of the Judgments on Merits, P.M., and M.C., among others, the vast majority of which are not mentioned in this paper), in order to obtain such compliance, with discouraging results on many occasions.

This explains why, in the cases in which the control of conventionality is established on the Judgment on Merits (Annex I), there are only two with Full Compliance (PACHECO TINEO FAMILY V. BOLIVIA, of 2013 and GARCIA IBARRA ET AL. V. ECUADOR, of 2015) and those in which it is mentioned in a M.C. (Annex II), there are only three in this condition (CASTILLO PETRUZZI ET AL. V. PERU, of 1999, LORI BERENSON MEJÍA V. PERU, of 2004 and CASTANEEDA GUTMAN V. MEXICO, of 2008).

Another aspect that draws deep attention is that within these cases there are some, considered emblematic and that are mentioned in practically every work in which the doctrine speaks of the control of conventionality, which are found Unfulfilled. This is particularly noticeable in the Cases DISMISSED CONGRESSIONAL EMPLOYEES (AGUADO - ALFARO ET AL.) V. PERU and LA CANTUTA V. PERU, both from 2006. And the other cases that are just as or more emblematic than the previous ones, are with Partial Compliance: ALMONACID ARELLANO ET AL. V. CHILE, of 2006, RADILLA PACHECO V. MEXICO, of 2009, CABRERA GARCÍA AND MONTIEL FLORES V. MEXICO, of 2010 and GELMAN V. URUGUAY, of 2011.

More generally, with respect to those other cases in which the control of conventionality is not mentioned in Judgments on Merits, but almost always in an M.C., the state of Non-Compliance and even abandonment of several of them is striking. In the first place, those that affect Guatemala, as expressed by the Court in the 12 GUATEMALAN'S CASES V. GUATEMALA. M. C., of $2015^{64}$. Apart from the cases referred to Guatemala, the LOAYZA TAMAYO V. PERU, of 1997, BARRIOS ALTOS V. PERU, of 2001, "FIVE PENSIONERS" V. PERU, of 2003 and ITUANGO MASSACRES V. COLOMBIA, of 2006 cases should also be taken into account.

Finally, the particularly serious situation of contempt of the APITZ BARBERA ET AL. ("FIRST COURT OF ADMINISTRATIVE DISPUTES") V. VENEZUELA, of 2008 and LÓPEZ MENDOZA V. VENEZUELA, of 2011, which have been notified to the General Assembly of the OAS, in accordance with the provisions of art. 65 of the American Convention on Human Rights, must be pointed out. The situation in the case of FONTEVECCHIA AND D'AMICO V. ARGENTINA, of 2011, has also generated considerable controversy in recent times ${ }^{65}$.

Hence, and in summary, in cases where the Court orders a control of conventionality in its Judgment on Merits, the level of compliance can be represented as follows ${ }^{66}$ :

\section{GRAPH 1 \\ LEVEL OF COMPLIANCE WITH CASES THAT ESTABLISH CONTROL OF CONVENTIONALITY IN THEIR JUDGMENTS ON MERITS}

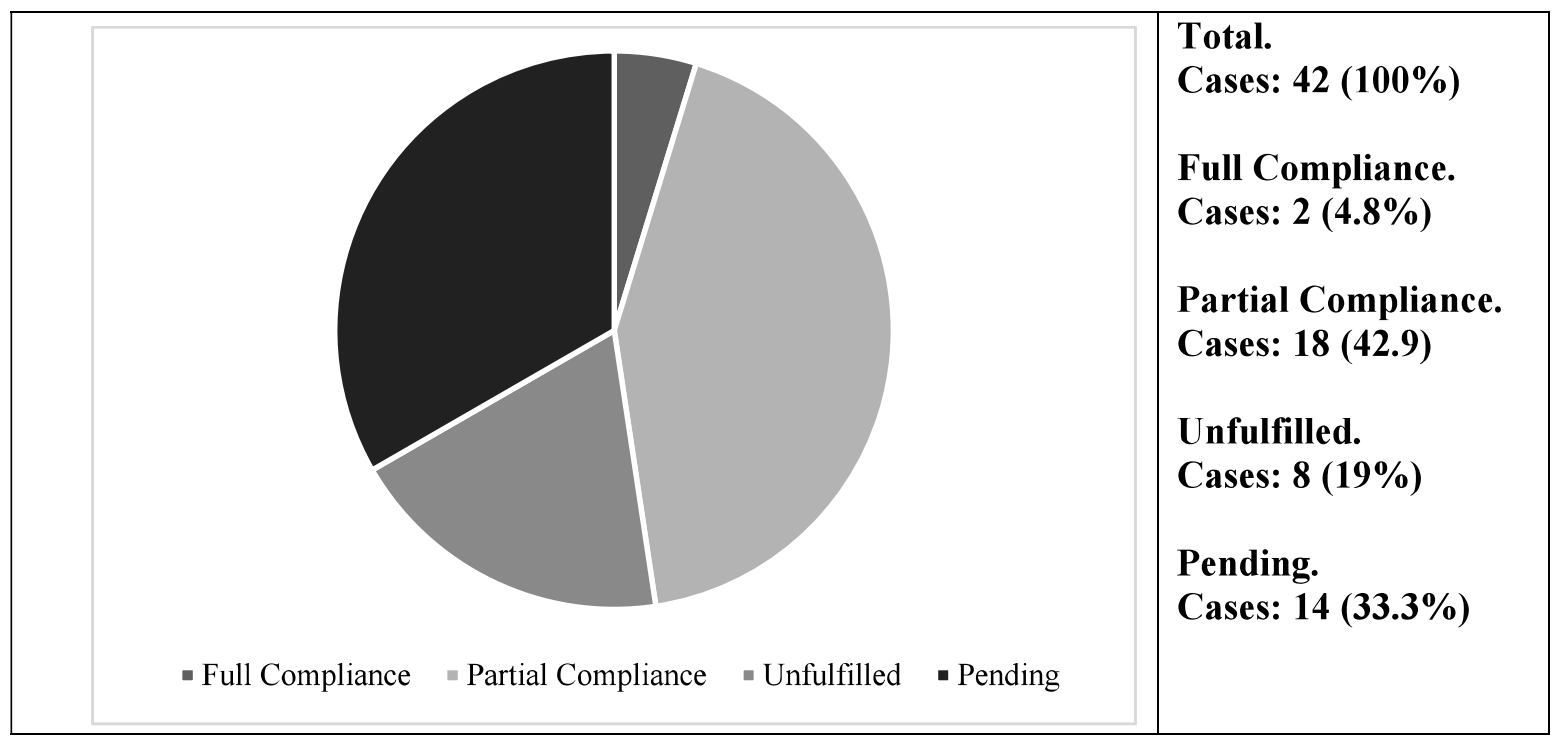

150 Journal of Applied Business and Economics Vol. 23(2) 2021 
On the other hand, if we take into account all the cases in which the Court refers to the control of conventionality analyzed in this work, the situation is as follows ${ }^{67}$ :

\section{GRAPH 2 \\ LEVEL OF COMPLIANCE WITH THE TOTAL NUMBER OF CASES IN WHICH CONVENTIONALITY CONTROL IS ESTABLISHED}

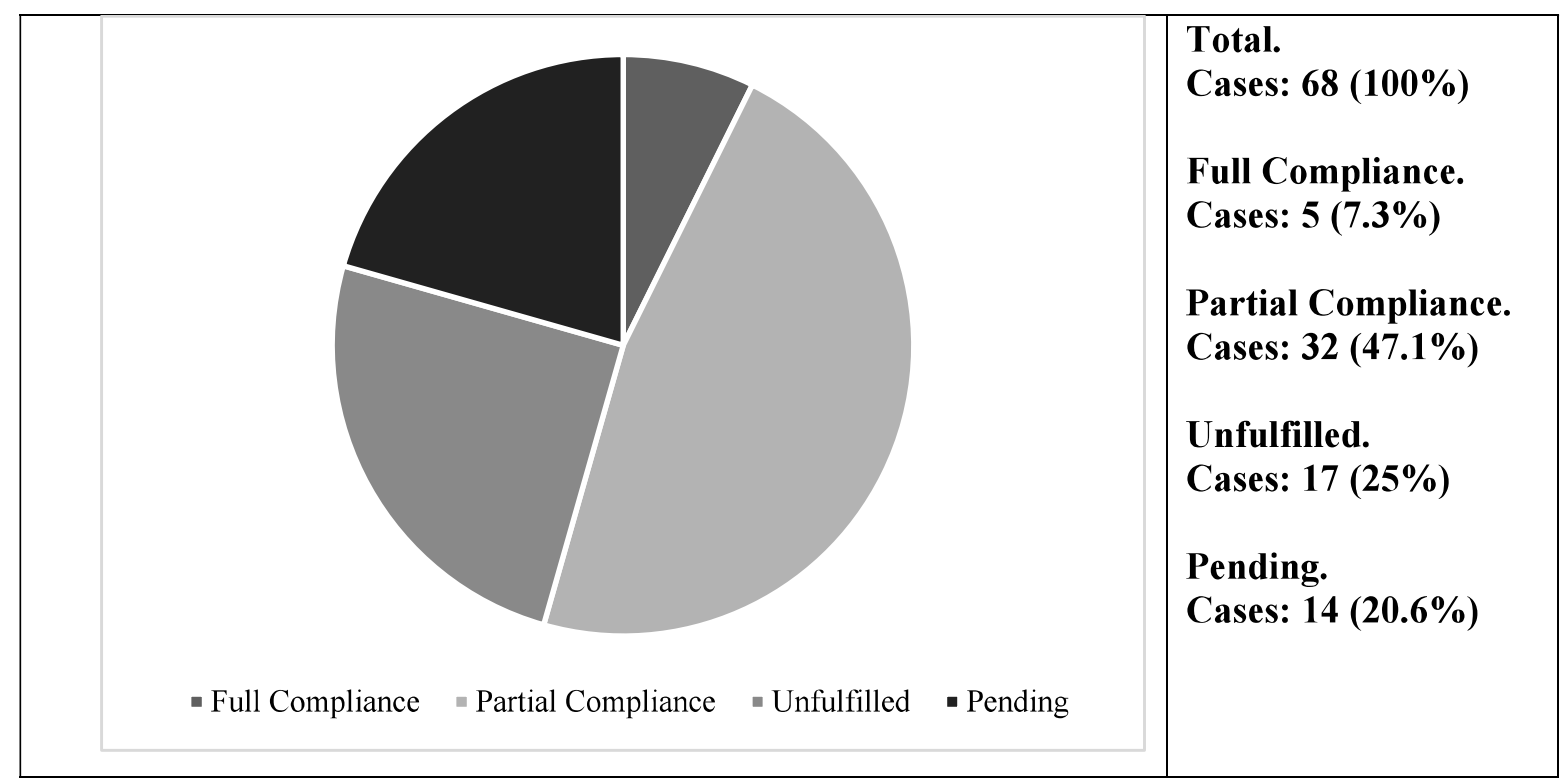

It can therefore be concluded that the level of compliance with the cases in which the Court establishes and advocates control of conventionality is very low, which could be partly due, in addition to the resistance of States, to the multiple benefits established in the Judgments on Merits, which undoubtedly makes compliance difficult ${ }^{68}$.

\section{A DIFFERENT APPROACH TO THE DOCTRINE OF CONTROL OF CONVENTIONALITY}

Now, if we take into account the low effectiveness of the rulings that order the aforementioned control of conventionality, it is legitimate to ask ourselves whether the consideration of this little known and almost always omitted fact could influence the way in which it is approached, or if we prefer, whether the way in which the majority doctrine has approached it would be different, if this information were added.

In our opinion, the response is positive, in particular and fundamentally, due to the leading role assigned to the Court to ensure that such control is correctly exercised. It can therefore be said without fear of error that the Inter-American Court is the cornerstone of this control. This is why we believe that this new fact is a key factor that must necessarily be added to the way in which the doctrine of conventionality is presented, all of which significantly alters its final result, to the point of making it quite unfeasible, at least in the way it is currently presented.

To demonstrate this, the main points of the theory of conventionality control set out in section 1 will be restated, taking into account this new information. To do so, we will first hypothetically analyze the situation that occurs with respect to the country condemned in the sentence that establishes it (by virtue of its inter partes effect), both with respect to the external control that the Court itself carries out, as well as the internal control that should later be carried out by the local authorities. Later, and in this same order external and internal--, the so-called erga omnes effect of the control of conventionality will be analyzed.

With regard to the inter partes effect, and even though this is a predictable fact, the low level of effectiveness of the judgments analyzed in this study clearly proves that no matter how much this court 
controls external conventionality, it has almost no way of forcing the condemned States to comply with its judgments, since such compliance will always depend on internal measures adopted by them, no matter how much pressure this international court exerts, among other channels, through its M.C.

That is why it is necessary to clarify (since it seems that sometimes the doctrine overlooks it) that it is not the same to order something to be done, as it is in the control of conventionality, than to carry it out by itself (in this case, by the Court itself), since every obligation is in itself vulnerable to violation, as this study shows.

However, as a general rule, this low level of compliance is a fact omitted by authors who analyze and advocate conventionality control. At most, some point out that in case of disagreement with the judgment, the State would have no alternative but to denounce the treaty, almost as if it were an insurmountable quandary ${ }^{69}$. But the truth is that in fact, the countries that have given jurisdiction to the Court continue to recognize it -except for Venezuela-, even when the level of compliance with its rulings is low ${ }^{70}$

Now, if these serious limitations exist with respect to external control in relation to the condemned State, with even greater reason there would be little possibility of supervising, first that the control of internal conventionality is carried out within that country and, assuming the above, that it is done correctly. However, the majority doctrine insists that whatever path the national judge adopts (i.e., not applying the national norm, making a conforming interpretation, making the local norm prevail, and also for some, giving rise to an extensive interpretation or even an innovative interpretation), he must do so following the criteria of the Court, and that otherwise, he would be giving rise to international responsibility of the State, since this court should always have the last word so that an adequate control of conventionality is conducted. Nevertheless, except for the specific case in which such control has not been applied or has been applied incorrectly comes to its knowledge after the internal instances have been exhausted, it is impossible for this Court to supervise it in other cases. From this standpoint, then, the leading role assigned to the Court seems quite unviable.

In fact, the only possible supervision could be achieved in the event that there is a persuasion on the part of local judges to follow the criteria of the Court, in particular those of the higher courts of each country, which could be achieved in part thanks to the 'interjurisdictional dialogue' for which so much is advocated. But this compliance is not only up to the local authorities; there is no guarantee that they will faithfully follow the criteria of this international tribunal, as it would be, for example, if they were inspired only by the treaty and not by its judgments, or by older jurisprudence emanating from it.

A similar impossibility of supervision exists, although it has not been addressed in this paper, with respect to the internal control of conventionality that, according to the Court, should be carried out by the other powers of the State and even by democratic bodies: unless a particular case of unconventionality comes to its attention after all internal avenues have been exhausted, there is no way that this court can take action. As we have seen, control of conventionality can hardly be a 'ray of destruction of local norms', nor does it necessarily lead to an inter-American ius commune.

Yet, even in cases where the unconventional internal action actually comes to the attention of the Court, we return to the initial problem of any external conventionality control: the impossibility for this court to force its execution by the condemned State.

In other words, for the Court, the only way to ensure that internal conventionality control is carried out properly is through the exercise of external control, for which it is necessary that the case comes to its attention and, if so, that the State complies with it.

Therefore, no matter how much it is said that the country would fall under international responsibility for not applying the control of conventionality (external or internal) or for applying it incorrectly, such responsibility may very well remain only on paper, since at most it would generate a new international responsibility ${ }^{71}$ and so on.

Finally, if there are problems in supervising the application of external and internal conventionality control with respect to the country condemned by a Court ruling by virtue of its inter partes effect, these problems are much more acute with respect to the rest of the countries that in theory should also apply it thanks to the hypothetical erga omnes effect of this control. This is unless, here too, national judges are persuaded to use the Court's criteria in preference to their own, but unlike in the previous case, with the 
added bonus that they are also prepared to follow the guidelines established by the Court in cases in which their country has not been a party. However, with the exception of this case, the only way to ensure that the control of conventionality in these other countries is carried out correctly would be for the situation to come to the attention of the Court, and the same problems already mentioned regarding the inter partes effect would arise.

Therefore, at least as things stand today, it does not seem possible to supervise the actions of these national judges whom the Court intends to turn into 'inter-American judges', so that in the end, only those cases in which conventionality control has not been applied or has been incorrectly used will come to the attention of this international tribunal. For the same reason, it does not seem so easy that a multiplier effect of its judgments could be generated and thus reach an inter-American ius commune. Unless there is an agreement in this sense by the local judges of each country as mentioned above, and unless it also coincides with the criteria of the Inter-American Court, there is no way in which these effects can occur.

In other words, encompassing all that has been said under this heading, it can be said that there is a lack of control over the control of conventionality. This is because in practice, the Court has no way of taking effective measures to ensure that its own external control of conventionality is applied in the first place, much less that local judges carry it out and, assuming the above, that they do so correctly.

All of the above -and this is fundamental- in view of the fact that the Court rules on approximately 25 cases per year, it is absolutely impossible for it to supervise the thousands and thousands of rulings that are issued throughout the continent ${ }^{72}$.

It could therefore be said that the poor compliance with the Court's judgments casts a considerable shadow of doubt over the doctrine of control of conventionality, both in its theoretical approach and in its practical application.

Moreover, since it is impossible for the Court to always have the last word, this could have the exact opposite effect to that desired: a complete dispersion of approaches to the application of the Convention and of the Court's jurisprudence. Therefore, it is not so easy that all the domestic law of each country ends up being 'thought, interpreted and made to work' according to the Court's jurisprudence, as has so often been mentioned.

Finally, and more generally, we believe that the omission of the actual level of compliance with the Court's judgments may lead to the error of thinking that compliance is relatively high. In fact, we must confess the profound surprise we had in discovering this fact, which is quite little known (otherwise it would be subject to analysis) after having investigated for quite some time the theory of the control of conventionality as presented by the majority doctrine. It was precisely this finding that motivated the present study.

Therefore, even if one understands the desire of the doctrine to make the Court's judgments as effective as possible in order to achieve better protection of human rights in the region, it seems to us that omitting this fact may be misleading, since the theoretical appearance of the control of conventionality -which may even give a sense of invulnerability, or even of being a fait accompli- is very different from its practical reality. Hence, this lack of control over the control of conventionality makes it, in our opinion, unviable, at least as it is posed by the majority doctrine.

\section{CONCLUSIONS}

The main conclusion of this paper is that if the actual level of compliance encountered in the cases in which the Inter-American Court has ordered the application of conventionality control is taken into account, the theory of it should be reformulated in light of this little-known fact.

Indeed, this low level of compliance demonstrates an aspect that is intuitive but should be made clear: that the Court has no way of forcing States to comply with its judgments. That is why the theory of control of conventionality, both external and internal, is not viable, at least in the way that the majority doctrine currently poses it, since it is impossible for this court to have the leading role that is assigned to it for its proper functioning. 
The above, acknowledging its factual impossibility to supervise the judgments of a whole continent, in view of the low number of judgments it issues each year.

That is why, in our opinion, the way in which the theory of the control of conventionality, above all, is presented by the doctrine -with a poise and security that almost gives one the impression of being before a consolidated situation-, is contradictory with the real level of compliance with the paradigmatic rulings (and several others) on which it is based. This is without omitting the fact that, since they are not established in the American Convention, these rulings are the only basis for conventionality control, given their praetorian origin

In part, this lack of effectiveness may be due, as indicated, to the abundant obligations established by the Court in each Judgment on Merits, which makes them difficult to comply with, in addition to requiring a long time, all of which also generates a notable wear and tear on this court, by obliging it to issue so many annexed rulings. But we believe that this is not enough to explain the described situation.

Consequently, this means that the majority doctrine does not present things as they are, but as they should be from its perspective. Such an approach is perfectly licit, but it should warn about what actually happens in practice, otherwise it can lead to confusion. That is why it would be desirable that dogmatics also consider the practical result of its postulates, incorporating this variable in the construction of its theoretical concepts.

All this makes one suspect that the theory of conventionality control has been formulated too theoretically and that the reality of its functioning and its real possibilities of implementation have not been properly taken into account.

This can be explained, among other things, by the fact that although the Inter-American Court seeks to establish itself as a kind of continental constitutional court, it remains an international court and therefore depends fundamentally on States for the effectiveness of its decisions, by virtue of its subsidiary nature in the protection of human rights.

\section{ACKNOWLEDGEMENT}

Translated \& Edited by American Publishing Services (https://americanpublishingservices.com/).

\section{ENDNOTES}

* This article was originally published in the Revista Chilena de Derecho, Pontificia Universidad Católica de Chile, vol. 45 No. 3, 2018, pp. 717-744.

1. GarCía (2011) pp. 144-145; CASTILla (2013) p. 53; DULITZKY (2015) pp. 50-52 y 54-55.

2. ALMONACID ARELLANO ET AL. V. CHILE (2006) paras. 123-125.

3. Castilla (2014) pp. 167-168; Nogueira (2012b) pp. 1167-1168; SAGÜÉs (n.d. b) p. 382

4. GARCíA (2011) pp. 123-159; BAZÁN (2012) pp. 24 and 31; CABALLERO (2011) pp. 119-129.

5. HitTERS (2008) p. 147; GARCÍA AND CONTRERAS (2014) pp. 217-218; HENRÍQUEZ (2014) pp. 123 and 131.

6. Castilla (2016) pp. 87-125; MeJía (2014) pp. 121-138; CONTESSE (2013) pp. 5-6.

7. From DISMISSED CONGRESSIONAL EMPLOYEES (AGUADO - ALFARO ET AL.) V. PERU (2006) paras. 128, in the great majority of judgments that refer to this issue.

8. For example, in CABRERA GARCÍA AND MONTIEL FLORES V. MEXICO (2010) paras. 225; GELMAN V. URUGUAY (2011) paras. 193; GELMAN V. URUGUAY. Monitoring Compliance (2013) paras. 66, 68-69, 71-72, 73-78, 8087,89 and 102. This is discussed in BAZÁN (2012) pp. 36-43; NOGUEIRA (2012b) pp. 1184, 1204-1217 and 1219; SAGÜÉS (2009) p. 2.

9. For example, in MASSACRES OF EL MOZOTE AND NEARBY PLACES V. EL SALVADOR (2012) paras. 318; MENDOZA ET AL.V. ARGENTINA (2013) paras. 323; ROCHAC HERNÁNDEZ ET AL. V. EL SALVADOR (2014) paras. 213; This is discussed in FERRER (2014) p. 238; NOGUEIRA (2012c) pp. 85, 93-94, 102-103 and 128.

10. GELMAN V. URUGUAY (2011) paras. 238-240; GELMAN V. URUGUAY. Monitoring Compliance (2013) paras. 69 (and note 48). This is discussed in HENRíQUEZ (2014) p. 123; NASH (2013) pp. 498-499; AgUILAR (2016a) pp. 337-365.

11. SAGÜÉS (2010) p. 130

12. NOGUEIRA (2012b) pp. 1181-1182; SAGÜÉS (2009) p. 3; SAGÜÉS (n.d. a) pp. 458-461. 
13. For example, in ROSENDO CANTÚ ET AL V. MEXICO (2010) paras. 220; CHOCRÓN - CHOCRÓN V. VENEZUELA (2011) paras. 172; RÍO NEGRO MASSACRES AND GUDIEL ÁLVAREZ ET AL. V. VENEZUELA. Monitoring Compliance (2014) paras. 16. This is discussed in CABALLERO (2011) pp. 109-112 and 120-122; CONTRERAS (2014) pp. 237-238, 254, 261 and 263; SAGÜÉs (2003) pp. 215-216.

14. For example, in ALMONACID ARELLANO ET AL.V. CHILE (2006) paras. 124; LA CANTUTA V. PERU (2006) paras. 173; GOMES LUND ET AL. ("GUERRILHA DO ARAGUAIA") V. BRAZIL. Monitoring Compliance (2014) paras. 16 and 18. This is discussed in NOGUEIRA (2013b) pp. 546-547; SAGÜÉs (2010) pp. 127-128; GARCÍA AND CONTRERAS (2014) pp. 217-218.

15. BAZÁN (2010) pp. 170-173; HENRÍQUEZ (2009) pp. 52-55; NÚÑEZ (2010) pp. 452-457 and 461-464.

16. HitTERS (2009) pp. 118 and 125; MEJ́́A (2014) p. 124; FERRER (2013) p. 666.

17. HitTERs (2013) pp. 708-709; CANÇADO (2006) pp. 310-314; FERRER (2013) p. 676.

18. FERRER (2011) pp. 424 and 427; HitTERS (2009) pp. 118 and 122; NOGUEIRA (2012c) pp. 62-63 and 90-98.

19. FERRER (2011) pp. 400-401; NOGUEIRA (2013c) p. 222; AGUILAR (2013) p. 645.

20. SAGÜÉs (n.d. a) pp. 462 and 468; MEIER (2011) pp. 334 and 371; PEREYRA (2011) pp. 167 and 173.

21. GARCÍA (2015) p. 136.

22. GELMAN V. URUGUAY. Monitoring Compliance (2013) paras. 67, 69, 71, and 102. Somewhat vaguely, LÓPEZ LONE ET AL. V. HONDURAS (2015) paras. 307. This is commented in CARBONELL (n.d.) pp. 79-83; HitTERS (2012) p. 548; PEREYRA (2011) pp. 160-161 and 170-172.

23. FERRER (2010) pp. 177 and 186; DULITZKY (2015) pp. 48 and 76.

24. CARBonell (n.d.) p. 80; Nogueira (2012b) pp. 1170 and 1195; DulitZKy (2015) p. 70.

25. FERRER (2014) p. 240; HitTERS (2013) p. 707; NOGUEIRA (2012c) pp. 79-81

26. DULITZKY (2014) p. 552; FERRER (2010) pp. 187-188

27. Nogueira (2013c) p. 269; DULITZKY (2015) p. 69; BAZÁN (2012) p. 28

28. NASH (2013) p. 505; CONTRERAS (2014) p. 260; AGUILAR (2013) p. 643

29. NOGUEIRA (2012a) p. 152; FERRER (2013) pp. 656, 679-382.

30. GARCíA (2011) p. 127; HitTERS (2008) note 98 (p. 153); SAGÜÉs (n.d. a) pp. 449-451 and 467.

31. BAZÁN (2012) p. 25; DULITZKY (2015) pp. 64-65; HITTERS (2008) p. 147.

32. With a different intensity, SAGÜÉs (2014) p. 18; FERRER (2013) pp. 670-671; HITTERS (2013) p. 705.

33. GOMES LUND ET AL. ("GUERRILHA DO ARAGUAIA") V. BRAZIL (2010) paras. 49; ESCHER ET AL. V. BRAZIL (2009) paras. 44; GELMAN V. URUGUAY. Monitoring Compliance (2013) paras. 37, 57-58, 68, 72, 88, 90 and 102. This is discussed in FERRER (2011) pp. 421-423; IBÁÑEZ (2012) pp. 111-112.

34. NOGUEIRA (2013b) pp. 521 and 532.

35. NOGUEIRA (2012c) p. 82.

36. SAGUÉs (n.d. b) p. 385. Italics in the original.

37. SAGÜÉS (2014) p. 17

38. FERRER (2013) pp. 657, 669, 671-672 and 677; NOGUEIRA (2012c) pp. 58-59, 64, 68, 71-72, 81, 84-85, 96, 100-102 and 124; MEIER (2011) pp. 332-333 and 369-371.

39. See supra note 17

40. ACOsta (2016) pp. 32-34; CASTILla (2011a) pp. 149-153; CASTILla (2011b) p. 598.

41. SILVA (2016) pp. 119-121 and 129-130.

42. FERRER (2011) pp. 421-423; IBÁÑEZ (2012) pp. 103 and 111-112.

43. NOGUEIRA (2012a) pp. 149-187; NOGUEIRA (2013a) pp. 221-274; FERRER (2014) p. 240

44. Nogueira (2012a) pp. 149-187; NogUeira (2013a) pp. 221-274; NogUeira (2013b) pp. 511-553.

45. Nogueira (2012c) pp. 89-90; NOGUEIRA (2013b) pp. 531-532; NOGUEIRA (2013c) pp. 234 and 248-249.

46. NOGUEIRA (2012c) p. 90.

47. NOGUEIRA (2012c) p. 90.

48. Nogueira (2013c) p. 234. For these ideas, NogueIRA (2012c) pp. 89-91, 103 and 110-121; NogUeIRA (2013b) pp. 521-522 and 532-533.

49. This is because it seems unlikely that the local judge would make an extensive or innovative interpretation if they were to apply the national rules on the basis of the pro homine principle seen in the previous paragraph.

50. Nogueira (2012c) pp. 90-98; AgUilar (2012) pp. 727-728 and 740-742; HitTers (2009) pp. 118 and 122.

51. BAZÁN (2010) pp. 170-173; CANÇADO (2006) pp. 416-417; TAPIA (2008) pp. 133-134.

52. FERRER (2010) p. 22; SAGÜÉS (n.d. b) pp. 385-386; CONTESSE (2013) p. 15.

53. OlANO (2017) pp. 66 and 87; AGUILAR (2016b) p. 131; FERRER (2016) pp. 340 and 342.

54. SAGÜÉS (2015), pp. 275-283

55. https://www.corteidh.or.cr/index.cfm?lang=en.

Journal of Applied Business and Economics Vol. 23(2) 2021155 
The last visit to all the websites listed in this paper was made on 29 March 2018.

The control of conventionality is also mentioned in other judgments that are not considered in this paper, because it is not the Court itself that does it, but the Inter-American Commission (MOHAMED V. ARGENTINA, of 2012, OMAR HUMBERTO MALDONADO VARGAS ET AL. V. CHILE, of 2015 and DUQUE V. COLOMBIA, of 2016) the State (as in the interpretations of Judgments on Merits of OSORIO RIVERA AND FAMILY V. PERU, of 2014) the victims' representatives (NADEGE DORZEMA ET AL. V. DOMINICAN REPUBLIC, of 2012 and DUQUE V. COLOMBIA, of 2016). Nor has consideration been given to comments on this issue made in reasoned, concurrent or dissenting votes.

In FERNÁNDEZ ORTEGA ET AL. V. MEXICO and ROSENDO CANTÚ ET AL V. MEXICO, both from 2010.

In RADILLA PACHECO V. MEXICO (2009) in its M.C. of 2012, 2013 and 2015; FERNÁNDEZ ORTEGA ET AL. V. MEXICO (2010), M.C. of 2015; ROSENDO CANTÚ ET AL.V. MEXICO (2010), M.C. of 2015; GOMES LUND ET AL. ("GUERRILHA DO ARAGUAIA") V. BRAZIL (2010), M.C. of 2014; CABRERA GARCÍA AND MONTIEL FLORES V. MEXICO (2010), M.C. of 2013 and 2015; GELMAN V. URUGUAY (2011), M.C. of 2013; RÍO NEGRO MASSACRES V. GUATEMALA (2012), M.C. of 2014; and GUDIEL ÁLVAREZ ET AL. ("DiARIO MILITAR") V. GUATEMALA (2012), M.C. of 2014.

https://www.corteidh.or.cr/supervision de cumplimiento.cfm?lang=en.

https://www.corteidh.or.cr/casos_en_supervision_por_pais_archivados.cfm?lang=en

https://www.corteidh.or.cr/galeria-multimedia.cfm?lang=en.

https://www.corteidh.or.cr/comunicados_prensa.cfm?lang=en.

12 GUATEMALAN'S CASES V. GUATEMALA. M. C. (2015) in particular, paras. 20, 126, 170, 174 and 175.

ABRAMOVICH (2017) pp. 9-25; FURFARO (2017) pp. 37-79.

Source: own elaboration.

Source: own elaboration.

While not referring to this problem of inefficiency, they approach these many features from different angles, PAÚL (2013) pp. 314-317 and 337-340; MALARINO (2011) pp. 27-29, 49-53 and 59-61.

SAGÜÉS (2010) p. 125; SAGÜÉs (n.d. a) pp. 456-458; SALGADO (2012) p. 236.

From very different perspectives, HAWKINS and JACOBY (2010) pp. 39, 43 and 51; CANÇADO (2013) pp. 3234.

VIO (2015) pp. 99-103.

DULITZKY (2014) pp. 552-553; DULITZKY (2015) pp. 48, $70-73$ and 76; SILVA (2016) pp. 125-128.

M. C. (2010) Declaration Points 1 and 2.

M. C. (November 20, 2009) Declaration Point 1; M. C. (2010) Declaration Points 1.

M. C. (2009) Declaration Points 1, 2 and 3.

M. C. (2011) Declaration Points 1, 2 and 3.

M. C. (2009) Declaration Point 1; M. C. (2010) Declaration Point 1; M. C. (2015) Declaration Point 1; M. C. (2016) Declaration Points 1 and 2.

M. C. (May 25, 2010) Declaration Point 1; M. C. (2012) Declaration Points 1 and 3; M. C. (2017) Resolution Points 1-3.

M. C. (May 19, 2011) Declaration Points 1 and 2; M. C. (December 01, 2011) Declaration Point 1; M. C. (2012) Declaration Point 1; M. C. (2013) Resolution Points 1 and 2; M. C. (2015) Resolution Point 1.

M. C. (2011) Declaration Points 1 and 2.

M. C. (2017) Resolution Points 1, 3c and 4.

M. C. (2014) Resolution Points 1 and 2; M. C. (2015) Resolution Points 1 and 2.

M. C. (2014) Resolution Points 1 and 2; M. C. (2015) Resolution Points 1 and 2.

M. C. (2013) Declaration Points 1 and 2.

M. C. (2013) Declaration Points 1 and 2.

M. C. (2014) Declaration Points $1,3,4,5$ and 6.

M. C. (2014) Resolution Points 1 and 2; M. C. (2015) Resolution Points 1 and 2.

M. C. (2013) Declaration Points 1, 2, 3 and 4.

M. C. (2015) Declaration Point 1; M. C. (2016) Declaration Points 1, 2 and 3.

M. C. (2015) Declaration Points 1 and 2.

M. C. (2015) Declaration Points 1 and 2; M. C. (2016) Declaration Points 1 and 2; M. C. (2017) Resolution Points 1-3.

M. C. (2013) Resolution Points 1 and 2; M. C. (2017) Resolution Points 1-3.

M. C. (2014) Resolution Point 1; M. C. (2017) Resolution Points 1-4.

M. C. (2017) Resolution Points 1 and 2. 
95. M. C. (2016) Resolution Point 1.

96. M. C. (2015) Resolution Points 1-5.

97. M. C. (2016) Resolution Points 1-5.

98. M. C. (2017) Resolution Points 1-3.

99. M. C. (2017) Resolution Points 1-6.

100. M. C. (2017) Resolution Points 1-5.

101. In this case, no reference is made to the control of conventionality in the Judgment on Merits.

102. M. C. (2006) Declaration Points 1 and 2; M. C. (March 09, 2008) Declaration Points 1 and 2; M. C. (March $28,2008)$ paras. $67-69$

103. M. C. (March 28, 2008) paras. 67-69; M. C. (September 09, 2008) Declaration Points 3, 4 and 5.

104. M. C. (May 22, 2009) Resolution Point 1; M. C. (September 21, 2009) Declaration Points 1, 2 and 3; M. C. (2010) Declaration Points 1 and 2; M. C. (2016) Resolution Points 1 and 2.

105. M. C. (2008) paras. 10; M. C. (2016) Resolution Points 1-5; M. C. (2009) Resolution Point 1.

106. M. C. (2003) Declaration Point 1; JoINT Monitoring ComplanCE of 11 CASES V. GUATEMala (2014) Resolution Point 1; 12 GUATEMALAN'S CASES V. GUATEMALA (2015) paras. 20, 63-72, 126, 170 and 175.

107. M. C. (2016) Resolution Points 1, 2 and 3.

108. M. C. (2016) Resolution Points 1-5.

109. M. C. (2001) paras. 13, Considering Point. 4 and Resolution Point 1; M. C. (2002) Considering Point. 6; M. C. (2005) Declaration Point 1; M. C. (2011) Declaration Points 1 and 2.

110. M. C. (2012) Declaration Points 1 and 2.

111. M. C. (2003) Declaration Points 3 and 4; M. C. (2004) Declaration Point 1; M. C. (2005) Declaration Point 1; M. C. (2008) Declaration Point 1; M. C. (2012) Declaration Points 1 and 2.

112. M. C. (2012) Resolution Points 1 al 4.

113. M. C. (2013) Resolution Points 1, 2 and 3.

114. M. C. (2013) Resolution Points 1-5.

115. M. C. (2013) Resolution Points 1 and 2.

116. M. C. (2009) Declaration Point 1; M. C. (2011) Declaration Points 1 and 2; M. C. (2013) Resolution Points 1,2 and 3

117. M. C. (2003) Declaration Point 1; 12 GUATEMALAN'S CASES V. GUATEMALA (2015) paras. 20, 46-52, 126, 170, 174 and 175 .

118. M. C. (2003) Declaration Point 1; M. C. (2005) Declaration Point 1; JOINT MONITORING COMPLIANCE OF 11 CASES V. GUATEMALA (2014) Resolution Point 1; 12 GUATEMALAN'S CASES V. GUATEMALA (2015) paras. 20, $56-62,126,170,174$ and 175.

119. M. C. (2005) Declaration Points 1, 2 and 3; M. C. (2007) paras. 15 and Declaration Points 1 and 2; M. C. (November 16, 2009) paras. 13 and Declaration Point 1; 12 GUATEMALAN'S CASES V. GUATEMALA (2015) paras. 20, 73-75, 126 and 173.

120. M. C. (2005) Declaration Point 1; JoINT Monitoring ComplanCE of 11 CASES V. GUATEMaLA (2014) Resolution Point 1; 12 GUATEMALAN'S CASES V. GUATEMALA (2015) paras. 20, 76-81, 126, 170, 174 and 175.

121. M. C. (2007) Resolution Points 1 and 2; M. C. (2008) Declaration Points 1 and 2; M. C. (2009) Declaration Points 1 and 2; M. C. (2011) Declaration Points 1 and 2; 12 GUATEMALAN'S CASES V. GuATEMALA (2015) paras. 20, 90-94, 126, 170, 174 and 175.; M. C. (2017) Resolution Points 1-4.

122. M. C. (2007) Declaration Point 1; JOINT MoNITORING COMPLIANCE OF 11 CASES V. GUATEMALA (2014) Resolution Point 1; 12 GUATEMALAN'S CASES V. GUATEMALA (2015) paras. 20, 82-89, 126, 170, 174 and 175.

123. M. C. (2007) Declaration Points 1 and 2; M. C. (2009) Declaration Point 1; 12 GUATEMALAN'S CASES V. GUATEMALA (2015) paras. 20, 95-100, 126, 170, 174 and 175.

124. M. C. (2011) Declaration Point 1; JOINT MoNitoring COMPLIANCE of 11 CASES V. GUATEMALA (2014) Resolution Point 1; 12 GUATEMALAN'S CASES V. GUATEMALA (2015) paras. 20, 101-107, 126, 170, 174 and 175.

125. M. C. (2011) Declaration Points 1 and 2; M. C. (2012) Declaration Point 1; 1212 GUATEMALAN'S CASES V. GUATEMALA (2015) paras. 20, 108-114, 126, 170, 174 and 175.

126. M. C. (2011) Declaration Points 1 and 2; S.C (2012) Declaration Point 1; JOINT MONITORING COMPLIANCE OF 11 CASES V. GUATEMALA (2014) Resolution Point 1; 12 GUATEMALAN'S CASES V. GUATEMALA (2015) paras. 20, 115-121, 126, 170, 174 and 175.

127. M. C. (2003) Considering Point 7 and Resolution Point 3; M. C. (November 27, 2007) Declaration Points 1 and 2; 12 GUATEMALAN'S CASES V. GUATEMALA (2015) paras. 20, 53-56, 126, 170, 174 and 175. 


\section{REFERENCES}

Abramovich, V. (2017). Comentarios sobre 'Fontevecchia', la autoridad de las sentencias de la Corte Interamericana y los principios de derecho público argentino (Comments on 'Fontevecchia', the authority of Inter-American Court judgments and Argentine public law principles). Pensar en Derecho, 5(10), 9-25.

Acosta Alvarado, P.A. (2016). Zombis vs Frankenstein: sobre las relaciones entre el Derecho Internacional y el Derecho interno (Zombies v. Frankenstein: on the interaction between domestic and international law). Estudios Constitucionales, 14(1), 15-60.

Aguilar Cavallo, G. (2012). El Control de Convencionalidad de los derechos. Comentario a la sentencia de la Corte Suprema de Chile en el caso denominado Episodio Rudy Cárcamo Ruiz de 24.5.12 (The Conventionality Control of rights. Commentary to the sentence of the Supreme Court of Chile in the case called Episode Rudy Cárcamo Ruiz of 24.5.12). Estudios Constitucionales, $10(2)$, pp. 717-750.

Aguilar Cavallo, G. (2013). «Afinando las cuerdas» de la especial articulación entre el Derecho Internacional de los Derechos Humanos y el Derecho Interno («Tuning the strings» of the special articulation between International Human Rights Law and Domestic Law)", Estudios Constitucionales, 11(1), 633-654.

Aguilar Cavallo, G. (2016a). Los derechos humanos como límites a la democracia a la luz de la jurisprudencia de la Corte Interamericana de Derechos Humanos (Human Rights as Restriction to the Democracy in the Light of the Inter-American Court of Human Rights Case-Law). Revista da AJURIS, 43(141), 337-365.

Aguilar Cavallo, G. (2016b). Constitucionalismo global, control de convencionalidad y el derecho a huelga en Chile (Global constitutionalism, control of conventionality and the right to strike in Chile)", Anuario Colombiano de Derecho Internacional (ACDI), 9, 113-166.

Bazán, V. (2010). En torno al control de las inconstitucionalidades e inconvencionalidades omisivas (En torno al control de las inconstitucionalidades e inconvencionalidades omisivas)", Anuario de Derecho Constitucional Latinoamericano, 16, 151-177.

Bazán, V. (2012). El control de convencionalidad: incógnitas, desafíos y perspectivas (The control of conventionality: unknowns, challenges and perspectives). in Bazán, Víctor and Nash, Claudio (Eds.), Justicia constitucional y derechos fundamentales. El control de convencionalidad 2011 (pp. 17-55). Santiago, Konrad Adenauer-Stiftung E.V.

Caballero Ochoa, J.L. (2011). La cláusula de interpretación conforme y el principio pro persona (art. $1^{\circ}$ segundo párrafo de la Constitución) (The conforming interpretation clause and the pro persona principle (art. 1, second paragraph, of the Constitution)). in Carbonell Sánchez, Miguel and Salazar Ugarte, Pedro (Coords.), La reforma constitucional de derechos humanos: un nuevo paradigma (pp. 103-133). México, Unam.

Cançado Trindade, A.A. (2006). El Derecho Internacional de los Derechos Humanos en el siglo XXI (International Human Rights Law in the 21 st Century), (Santiago, Editorial Jurídica de Chile, segunda edición).

Cançado Trindade, A.A. (2013). Compliance with Judgments and Decisions - The Experience of the Inter-American Court of Human Rights: a Reassessment", Revista do Instituto Brasileiro de Dereitos Humanos, 13(13), 29-36.

Carbonell, M. (n.d.). Introducción general al control de convencionalidad (General introduction to conventionality control). Retrieved November 11, 2015, from http://biblio.juridicas.unam.mx/libros/7/3271/11.pdf.

Castilla Juárez, K. (2011a). Un nuevo panorama constitucional para el derecho internacional de los derechos humanos en México (A new Constitutional panorama for the International Human Rights Law in Mexico). Estudios Constitucionales, 9(2), 123-164. 
Castilla Juárez, K. (2011b). El control de convencionalidad; un nuevo debate en México a partir de la sentencia del caso Radilla Pacheco (Conventionality Control: A new debate in Mexico from Radilla Pacheco Judgment). Anuario Mexicano de Derecho Internacional, XI, 593-624.

Castilla Juárez, K. (2013). ¿Control interno o difuso de convencionalidad? Una mejor idea: la garantía de los tratados (National or Diffuse Conventionality Control? A Better Idea: the Warranty of Treaty). Anuario Mexicano de Derecho Internacional, XIII, pp. 51-97.

Castilla Juárez, K. (2014). Control de convencionalidad interamericano: una mera aplicación del Derecho Internacional (Inter-American conventionality control: A simple application of International Law), Revista Derecho del Estado, (33), 149-172.

Castilla Juárez, K. (2016). Control de convencionalidad interamericano: Una propuesta de orden ante diez años de incertidumbre (Control of Inter-American Conventions: A Proposal for Order in the Face of Ten Years of Uncertainty). Revista IIDH, 64, 87-125.

Contesse, J. (2013). ¿La última palabra? Control de convencionalidad y posibilidades de diálogo con la Corte Interamericana de Derechos Humanos (The last word? Control of conventionality and possibilities of dialogue with the Inter-American Court of Human Rights)". Retrieved March 28, 2016, from http://www.law.yale.edu/documents/pdf/sela/SELA13_Contesse_CV_Sp_20130401.pdf.

Contreras, P. (2014). Control de convencionalidad, deferencia internacional y discreción nacional en la jurisprudencia de la Corte Interamericana de Derechos Humanos (Conventionality Control, International Deference, and National Discretion in the Inter-American Court of Human Rights Case Law). Ius et Praxis, 20(2), 235-274.

Dulitzky, A.E. (2014). El impacto del control de convencionalidad. ¿Un cambio de paradigma en el sistema interamericano de derechos humanos? (The Impact of Conventionality Control: A Paradigm Shift in the Inter-American Human Rights System?) in J.C. Rivera, et al (Dirs.), Tratado de los derechos constitucionales (pp. 533-569). Buenos Aires, Abeledo Perrott.

Dulitzky, A.E. (2015). An Inter-American Constitutional Court? The Invention of the Conventionality Control by the Inter-American Court of Human Rights. Texas International Law Journal, 50(1), 45-93.

Ferrer Mac-Gregor, E. (2010). El control difuso de convencionalidad en el Estado constitucional (The diffuse control of conventionality in the constitutional state). Retrieved September 12, 2016, from http://biblio.juridicas. unam.mx/libros/6/2873/9.pdf.

Ferrer Mac-Gregor, E. (2011) Interpretación conforme y control difuso de convencionalidad. El nuevo paradigma para el juez mexicano (Conformal interpretation and diffuse control of conventionality. The new paradigm for the Mexican judge). in M. Carbonell, \& P. Salazar, (Eds.), Derechos humanos; un nuevo modelo constitucional (pp. 339-429). México, Unam.

Ferrer Mac-Gregor, E. (2013). Eficacia de la sentencia interamericana y la cosa juzgada internacional: vinculación directa hacia las partes (res judicata) e indirecta hacia los estados parte de la Convención Americana (res interpretata) (sobre el cumplimiento del caso Gelman vs Uruguay) (Effectiveness of the inter-American judgment and international res judicata: direct link to the parties (res judicata) and indirect link to the states parties to the American Convention (res interpretata) (on compliance with the Gelman v. Uruguay case)). Estudios Constitucionales, 11(2), 641-693.

Ferrer Mac-Gregor, E. (2014) Control de convencionalidad (sede interna) (Conventionality control (internal headquarters)). in E. Ferrer Mac-Gregor, et al (Coords.), Diccionario de Derecho Procesal Constitucional y Convencional (pp. 236-240).México, Unam, segunda edición.

Ferrer Mac-Gregor, E. (2016). El control de convencionalidad como un vehículo para el diálogo judicial entre la Corte Interamericana de Derechos Humanos y los tribunales de América (Conventionality control as a vehicle for judicial dialogue between the Inter-American Court of Human Rights and the courts of the Americas). Anuario de Derecho Constitucional Latinoamericano, 22, 337-356. 
Furfaro, L. (2017). Las ataduras de Ulises se aflojan: el pronunciamiento de la CSJN frente al caso 'Fontevecchia' de la Corte IDH (Ulysses' Ties Loosen: NSC Statement on the IACHR 'Fontevecchia' Case). Pensar en Derecho, 5(10), 37-79.

García Pino, G., \& Contreras Vásquez, P. (2014). Diccionario Constitucional Chileno (Chilean Constitutional Dictionary), (Santiago, Cuadernos del Tribunal Constitucional $N^{\circ} 55$ ).

García Ramírez, S. (2011). El control judicial interno de convencionalidad (The internal judicial control of conventionality). IUS, Revista del Instituto de Ciencias Jurídicas de Puebla, 5(28), 123-159.

García Ramírez, S. (2015). The Relationship between Inter-American Jurisdiction and States (National Systems): Some Pertinent Questions. Notre Dame Journal of International \& Comparative Law, 5(1), 115-151.

Hawkins, D., \& Jacoby, W. (2010). Partial compliance: a comparison of the European and Inter-American Courts of Human Rights. Journal of International Law and International Relations, 6(1), 35-85.

Henríquez Viñas, M. (2009). Las fuentes formales del Derecho, The Formal Sources of Law. Santiago, Legal Publishing.

Henríquez Viñas, M. (2014). La polisemia del control de convencionalidad interno (Polysemy of Internal Conventionality Control). International Law, Revista Colombiana de Derecho Internacional, 24, 113-341.

Hitters, J.C. (2008, July-December). ¿Son vinculantes los pronunciamientos de la Comisión y de la Corte Interamericana de Derechos Humanos? (control de constitucionalidad y convencionalidad) (Are the pronouncements of the Commission and the Inter-American Court of Human Rights binding? (control of constitutionality and conventionality)). Revista Iberoamericana de Derecho Procesal Constitucional, (10), 131-156.

Hitters, J.C. (2009). Control de constitucionalidad y control de convencionalidad. Comparación (Criterios fijados por la Corte Interamericana de Derechos Humanos) (Control of constitutionality and control of conventionality comparison (Criteria set by the Inter-American Court of Human Rights)), Estudios Constitucionales, 7(2), 109-128.

Hitters, J.C. (2012). El control de convencionalidad y el cumplimiento de las sentencias de la Corte Interamericana (The control of conventionality and compliance with the judgments of the InterAmerican Court). Estudios Constitucionales, 10(2), 535-574.

Hitters, J.C. (2013). Un avance en el control de convencionalidad. (El efecto «erga omnes» de las sentencias de la Corte Interamericana) (A breakthrough in conventionality control. (The «erga omnes» effect of the judgments of the Inter-American Court)). Estudios Constitucionales, 11(2), 695-710.

Ibáñez Rivas, J.M. (2012). Control de convencionalidad: precisiones para su aplicación desde la jurisprudencia de la Corte Interamericana de Derechos Humanos (Control of conventionality: clarifications for its application from the jurisprudence of the Inter-American Court of Human Rights). Anuario de Derechos Humanos, 8, 103-113.

Malarino, E. (2011). Activismo judicial, punitivización y nacionalización. Tendencias antidemocráticas y antiliberales de la Corte Interamericana de Derechos Humanos (Judicial activism, punitivization and nationalization Anti-democratic and anti-liberal tendencies of the Inter-American Court of Human Rights)", in Grupo Latinoamericano de Estudios sobre Derecho Penal Internacional, Sistema Interamericano de Protección de los Derechos Humanos y Derecho Penal Internacional (Montevideo, Konrad-Adenauer-Stiftung e. V.) pp. 25-61.

Meier García, E. (2011). Nacionalismo constitucional y Derecho Internacional de los Derechos Humanos (Constitutional nationalism and international law of human rights), Estudios Constitucionales, 9(2), 329-376.

Mejía Lemos, D.G. (2014). On the «Control de Convencionalidad» Doctrine: a Critical Appraisal of the Inter-American Court of Human Rights' Relevant Case Law", Anuario Mexicano de Derecho Internacional, XIV, 117-151.

Nash Rojas, C. (2013). Control de convencionalidad. Precisiones conceptuales u desafíos a la luz de la jurisprudencia de la Corte Interamericana de Derechos Humanos (Conventionality control.

160 Journal of Applied Business and Economics Vol. 23(2) 2021 
Conceptual clarifications or challenges in light of the jurisprudence of the Inter-American Court of Human Rights). Anuario de Derecho Constitucional Latinoamericano, 19, 489-509.

Nogueira Alcalá, H. (2012a). El uso del derecho convencional internacional de los derechos humanos en la jurisprudencia del Tribunal Constitucional chileno en el período 2006-2010 (The use of International Treaty Law of Human Rights in the Jurisprudence of the Constitutional Court of Chile in the Period 2006-2010). Revista Chilena de Derecho, 39(1), 149-187.

Nogueira Alcalá, H. (2012b). Los desafíos del control de convencionalidad del corpus iuris interamericano para las jurisdicciones nacionales (The challenges of control of conventionality of the corpus iuris inter-american to national jurisdictions), Boletín Mexicano de Derecho Comparado, 45(135), 1167-1220.

Nogueira Alcalá, H. (2012c). Diálogo interjurisdiccional, control de convencionalidad y jurisprudencia del Tribunal Constitucional en el período 2006-2011 (Interjurisdictional dialogue, control of conventions and jurisprudence of the Constitutional Court in the period 2006-2011). Estudios Constitucionales, 10(2), 57-140.

Nogueira Alcalá, H. (2013a). El uso del derecho y jurisprudencia constitucional extranjera de tribunales internacionales no vinculantes por el Tribunal Constitucional chileno en el período 2006-2011 (The use of foreign constitutional law and jurisprudence of non-binding international courts by the Chilean Constitutional Court in the period 2006-2011). Estudios Constitucionales, 11(1), 221-274.

Nogueira Alcalá, H. (2013b). Diálogo interjurisdiccional y control de convencionalidad entre los tribunales nacionales y la Corte Interamericana de Derechos Humanos en Chile (Interjurisdictional dialogue and control of conventions between national courts and the Inter-American Court of Human Rights in Chile), Anuario de Derecho Constitucional latinoamericano, 19, 511-553.

Nogueira Alcalá, H. (2013c). El control de convencionalidad y el diálogo interjurisdiccional entre tribunales nacionales y Corte Interamericana de Derechos Humanos (Conventionality control and interjurisdictional dialogue between national courts and the Inter-American Court of Human Rights), Revista de Derecho Constitucional Europeo, 10(19), 221-270.

Núñez Poblete, M. (2010). Sobre la declaración de inaplicabilidad de los tratados internacionales. Un estudio en defensa de su fundamento y legitimidad (Inapplicability Judgment of International Treaties. A Study in Defense of its Rationale and Legitimacy) Estudios Constitucionales, 8(2), 461-464.

Olano García, H.A.(2017). Teoría del Control de Convencionalidad (Conventionality Control Theory)", Estudios Constitucionales, 14(1), pp. 61-94.

Paúl Díaz, Á. (2013). La Corte Interamericana in vitro: notas sobre su proceso de toma de decisiones a propósito del Caso Artavia (The Inter-American Court in Vitro: Commentaries on its DecisionMaking Process in Light of the Artavia Case). Revista Derecho Público Iberoamericano, 1(2), 303-345.

Pereyra Zabala, G. (2011). El control de convencionalidad en el sistema interamericano de derechos humanos (Conventionality control in the inter-American human rights system)", Revista de Derecho, 6, 155-176.

Sagüés, N.P. (2003). Las relaciones entre los tribunales internacionales y los tribunales nacionales en materia de derechos humanos. Experiencias en Latinoamérica (Relations between international courts and national courts in the field of human rights Experiences in Latin America)", Ius et Praxis, 9(1), 205-221.

Sagüés, N.P. (2014). Derechos constitucionales y derechos humanos. De la Constitución Nacional a la Constitución «convencionalizada» (Constitutional and human rights. From the National Constitution to the «conventionalized» Constitution), in Nogueira Alcalá, Humberto (Coord.), La protección de los derechos humanos y fundamentales de acuerdo a la constitución y el Derecho Internacional de los Derechos Humanos (Santiago, Librotecnia) pp. 15-23.

Sagüés, N.P. (2015). Las opiniones consultivas de la Corte Interamericana, en el control de convencionalidad (The advisory opinions of the Inter-American Court, in the control of conventionality). Pensamiento Constitucional, 20, 275-283. 
Sagüés, N.P. (n.d. a). El «Control de convencionalidad» como instrumento para la elaboración de un ius commune interamericano (The «Control of Conventionality» as an instrument for the elaboration of an inter-American ius commune). Retrieved March 15, 2016, from http://biblio.juridicas.unam.mx/libros/6/2895/15.pdf.

Sagüés, N.P. (n.d.b). El 'control de convencionalidad' en el sistema interamericano y sus anticipos en el ámbito de los derechos económico-sociales. Concordancias y diferencias con el sistema europeo (The 'control of conventionality' in the inter-American system and its advances in the field of economic and social rights. Concordances and differences with the European system)". Retrieved December 5, 2016, from http://biblio.juridicas.unam.mx/libros/7/3063/16.pdf.

Sagüés, Néstor P. (2009, February 19).El 'control de convencionalidad', en particular sobre las constituciones nacionales (The 'control of conventionality', in particular over national constitutions). La Ley, 1. Retrieved October 3, 2016, from

http://www.joseperezcorti.com.ar/Archivos/DC/Articulos/Sagues_Control_de_Convencionalidad LL_2009.pdf.

Sagüés, Néstor P. (2010). Obligaciones internacionales y control de convencionalidad (International obligations and conventionality control)", Estudios Constitucionales, 8(1), 117-136.

Salgado Ledesma, E. (2012, June-December). La probable inejecución de las sentencias de la Corte Interamericana de Derechos Humanos (The Likely Nonperformance of Judgments of the InterAmerican Court of Human Rights). Revista Mexicana de Derecho Constitucional, 26, 221-260.

Silva Abbott, M. (2016). Control de convencionalidad interno y jueces locales: un planteamiento defectuoso (Internal control of conventionality and local judges: a faulty approach)", Estudios Constitucionales, 14(2), 101-142.

Tapia Valdés, J. (2008). Poder constituyente irregular: los límites metajurídicos del poder constituyente originario (Irregular constituent power: the meta-legal limits of original constituent power)", Estudios Constitucionales, 6(2), 133-134.

Vio Grossi, E. (2015). Jurisprudencia de la Corte Interamericana de Derechos Humanos: ¿del control de convencionalidad a la supranacionalidad? (Jurisprudence of the Inter-American Court of Human Rights: from conventionality control to supranationality?). Anuario de Derecho Constitucional Latinoamericano, 21, 93-112.

\section{CASE LAW CITED}

INTER-AMERICAN COURT OF HUMAN RighTS. Judgments. Retrieved May 30, 2018, from https://www.corteidh.or.cr/casos_sentencias.cfm?lang=en.

INTER-AMERICAN COURT OF HUMAN RIG̈HTS. Orders on Provisional Measures. Retrieved May 30, 2018, from https://www.corteidh.or.cr/medidas_provisionales.cfm?lang=en.

INTER-AMERICAN COURT OF HUMAN RIGHTS. Orders of the Monitoring Compliance with Judgment. Retrieved May 30, 2018, from https://www.corteidh.or.cr/supervision_de_cumplimiento.cfm?lang=en.

\section{ANNEX I}

The following is a chronological list of the cases in which the Inter-American Court of Human Rights refers to the doctrine of control of conventionality in its Judgements on Merits up to December 2017 and, if applicable, also in some Interpretation of Judgments or in a Monitoring Compliance. The paragraphs in which this occurs are indicated, as well as the current status of the case (Full Compliance, Partial Compliance, Unfulfilled and Pending), indicating in the first three cases in a footnote, the Resolution Points or Declaration Points of the Monitoring Compliance ("M.C.") of each case that support this qualification. In the Pending cases, there is no footnote, as no M.C. has yet been issued to indicate the actual status of the case, which, in essence, may be Unfulfilled or with Partial Compliance. It should be noted that almost all of these M.C.'s are different from those indicated in the present list, but all have been extracted from the 
14. GOMES LUND ET AL. (“GUERRILHA DO ARAGUAIA”) V. BRAZIL. November 24, 2010. Series $C \mathrm{~N}^{\circ} 219$, paras. 49,176 and $177^{86}$.

PARTIAL

a. M. C. October 17, 2014, paras. 16, 18 and 19.

15. CABRERA GARCÍA AND MONTIEL FLORES V. MEXICO. November 26, 2010 Series C N 220 , paras. 21 and $225-233^{87}$.

PARTIAL COMPLIANCE

a. M. C. August 21, 2013, paras. 5, 29 (and note 16) and 37 (and note 21).

b. M. C. April 17, 2015, paras. 16 and 21.

16. GELMAN V. URUGUAY. February 24, 2011 Series $\mathrm{C} \mathrm{N}^{\circ}$ 221, paras. 193 and $239^{88}$.

a. M. C. March 20, 2013, paras. 37, 57-90 and 102.

17. CHOCRÓN - CHOCRÓN V. VENEZUELA. July 1, 2011. Series C $\mathrm{N}^{\mathrm{o}} 227$, paras. $164-172^{89}$.

18. LÓPEZ MENDOZA V. VENEZUELA. September 1, 2011. Series $\mathrm{C} \mathrm{N}^{\circ} 233$, paras. $226-228^{90}$

19. FONTEVECCHIA AND D'AMICO V. ARGENTINA. November 29, 2011. Series C No 238 , para. $93^{91}$.

a. M. C. October 18, 2017. para. 25.

20. ATALA RIFFO AND DAUGHTERS V. CHILE. February 24, 2012. Series C No 239, paras. $282-284^{92}$.

a. M. C. February 10, 2017, paras. 20 (note 27) and 25 (note 36 ).

21. FURLAN AND FAMILY V. ARGENTINA. August 31, 2012. Series C No 246, paras. 303-305.

22. RÍo NEGRO MASSACRES V. GUATEMALA. September 4, 2012. Series C N ${ }^{\circ} 250$, para. $262^{93}$.

a. M. C. August 21, 2014, paras. 16 and 17.

23. Massacres of El Mozote and nearby places v. El Salvador. October 25, 2012. Series C No 252 , paras. $318,{ }^{94}$.

PARTIAL COMPLIANCE

24. Gudiel Álvarez et al. (“Diario Militar") v. Guatemala. November 20, 2012. Series C N 253 , paras. $330^{95}$.

UNFULFILLED
UNFULFILLED

PARTIAL COMPLIANCE

PARTIAL COMPLIANCE

PENDING

UNFULFILLED

a. M. C. August 21, 2014, paras. 16 and 17.

25. SANTO DOMINGO MASSACRE V. COLOMBIA. November 30, 2012. Series $\mathrm{N}^{\circ} 259$, paras. 142.

PENDING

164 Journal of Applied Business and Economics Vol. 23(2) 2021 
26. MENDOZA ET AL. V. ARGENTINA. May 14, 2013. Series C N² 260, paras. 221, 257,323 and 332.

27. PACHECo TineO FAMILY V. PLURINATIONAL StATE OF BOLIVIA. November 25 , 2013. Series $C N^{\circ} 272$, para. $234^{96}$.

28. GARCÍA CRUZ AND SÁNCHEZ SILVESTRE V. MEXICO. November 26, 2013. Series $\mathrm{C} \mathrm{N}^{\circ} 273$, note 76 (para. 59) and para. $91^{97}$.

29. J. V. PERU. November 27, 2013. Series $\mathrm{C} \mathrm{N}^{\circ} 275$, para. 407.

30. LIAKAT ALI ALIBUX V. SURINAME. January 30, 2014. Series C No 276, paras. 124-125 and 151.

31. Norín Catrimán et al. (Leaders, members and activist of the Mapuche Indigenous People) v. Chile. May 29, 2014. Series $C^{\circ} N^{\circ} 279$, paras. 436, 461 and 464 .

32. EXPELLED DOMINICANS AND HAITIANS V. DOMINICAN REPUBLIC. August 28, 2014. Series $C N^{\circ} 282$, paras. 311,453 and 471.

33. ROCHAC HERNÁNDEZ ET AL. V. EL SALVADOR. October 14, 2014. Series C No 285 , para. $213^{98}$.

a. M. C. February 09, 2017, para. $17 \mathrm{~d}$.

34. LÓPEZ LONE ET AL. V. HONDURAS. October 5, 2015. Series C $\mathrm{N}^{\circ} 302$, para. $307^{99}$.

35. GARÍFunA PUNTA PIEDRA COMMUNITY AND ITS MEMBERS V. HONDURAS. October 8, 2015. Series $\mathrm{C} \mathrm{N}^{\circ} 304$, paras. 211, 255 and 346.

36. Community Garífuna Triunfo de la Cruz $\&$ its members v. Honduras. October 8, 2015. Series $\mathrm{C} \mathrm{N}^{\mathrm{o}} 305$, para. 267.

37. GARCÍA IBARRA ET AL. V. ECUADOR. November 17, 2015. Series C N 306 , paras. 103 and note $125^{100}$.

38. TENORIO ROCA ET AL. V. PERU. June 22, 2016. Series C $\mathrm{N}^{\circ} 314$, paras. 230 and 231.

39. Members of the village of Chichupac and neighboring communities of the Municipality of Rabinal v. Guatemala. November 30, 2016. Series C No 328 , para. 207.

40. ANDRADE SALMÓN V. BOLIVIA. December 1, 2016. Series C N³30, paras. 93 (and note 156), 94 and 102.
PENDING

FULL

COMPLIANCE

PARTIAL COMPLIANCE

PENDING

PENDING

PENDING

PENDING

PARTIAL COMPLIANCE

PARTIAL COMPLIANCE

PENDING

PENDING

FULL

COMPLIANCE

PENDING

PENDING 
41. VEREDA LA ESPERANZA V. COLOMBIA. August 31, 2017. Series $\mathrm{C} \mathrm{N}^{\circ} 341$, para. 261.

42. a. POLLO RIVERA ET AL. V. PERU. REQUEST FOR INTERPRETATION May 25, 2017. Series $C N^{\circ} 335$, paras. 2,13 and $15^{101}$.
PENDING

PENDING

\section{ANNEX II}

The following is a list of the cases in which the Inter-American Court of Human Rights refers to the doctrine of control of conventionality up to December 2017, not in its Judgements on Merits, but as a general rule, in some subsequent M. C., because they are cases that were decided before the appearance of this doctrine. For this reason, the chronology of this Appendix II depends on the date of this M. C., not on the date of the final judgment. The paragraphs that refer to this control are indicated, as well as the current status of the case (Full Compliance, Partial Compliance and Unfulfilled), indicating in a footnote the Resolution Points or Declaration Points of the Monitoring Compliance ("M.C.") and eventually, of Provisional Measures of each case that support this classification. It should be noted that most of these M.C. are different from those indicated in this list, but all have been extracted from the Court's website (https://www.corteidh.or.cr/supervision_de_cumplimiento.cfm?lang=en) and can be accessed under the name of the final judgment indicated here and the year, which is indicated in the footnote. When the exact date of an M.C. is mentioned, it is because there are two in that year for the same case. Finally, due to its age, there are no Pending cases here, as in Annex I.

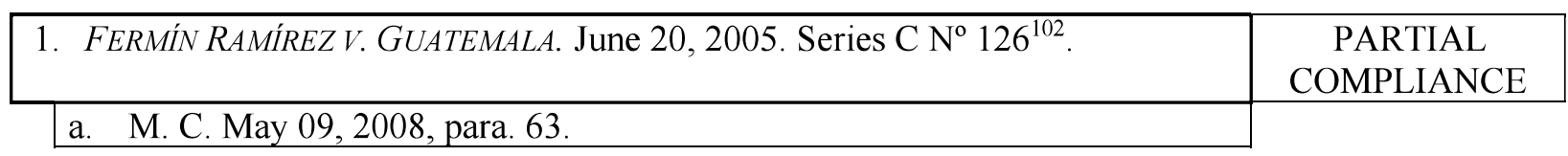

\begin{tabular}{l|l|c|}
\hline \multicolumn{2}{|l|}{ 2. RAXCACÓ REYES V. GUATEMALA. September 15, 2005. Series C N $133^{103}}$. & PARTIAL \\
COMPLIANCE \\
\hline
\end{tabular}

\begin{tabular}{|c|c|}
\hline 3. ZAMBRANO VÉLEZ ET AL. V. ECUADOR. July 4, 2007. Series C No $166^{104}$. & $\begin{array}{c}\text { PARTIAL } \\
\text { COMPLIANCE }\end{array}$ \\
\hline a. M. C. September 21, 2009, para. 42. & \\
\hline
\end{tabular}

\begin{tabular}{|c|c|}
\hline 4. “FIVE PENSIONERS” V. PERU. February 28, 2003. Series C $\mathrm{N}^{\circ} 98^{105}$. & $\begin{array}{c}\text { PARTIAL } \\
\text { COMPLIANCE }\end{array}$ \\
\hline a. M. C. November 24, 2009, para. 35. & \\
\hline
\end{tabular}

\begin{tabular}{|c|c|}
\hline 5. BÁMACA VELÁSQUEZ V. GUATEMALA. November 25,2000 . Series C $\mathrm{N}^{\circ} 70^{106}$. & UNFULFILLED \\
\hline a. M. C. November 18,2010 , para. 33. & \\
\hline $\begin{array}{l}\text { b. JOINT MONITORING COMPLIANCE OF II CASES V. GUATEMALA. M. C. } \\
\text { August 21, 2014, para. } 17 .\end{array}$ & \\
\hline $\begin{array}{l}\text { c. } 12 \text { GUATEMALAN'S CASES V. GUATEMALA. M. C. November 24, 2015, paras. } \\
26 \text { and } 142 .\end{array}$ & \\
\hline
\end{tabular}

\begin{tabular}{|c|c|}
\hline 6. WONG HO WING V. PERU. June 30, 2015. Series C N $297^{107}$. & $\begin{array}{c}\text { PARTIAL } \\
\text { COMPLIANCE }\end{array}$ \\
\hline $\begin{array}{l}\text { a. Provisional Measures with Regard to the Republic of Peru. October 10, } \\
2011 \text {, para. 11. }\end{array}$ & \\
\hline
\end{tabular}

166 Journal of Applied Business and Economics Vol. 23(2) 2021 
7. Castillo Petruzzi et Al. V. Peru. May 30, 1999. Series $\mathrm{C} \mathrm{N}^{\circ} 52^{108}$.

FULL COMPLIANCE

a. M. C. July 01, 2011, para. 20.

8. LOAYZA TAMAYO V. PERU. September 17, 1997. Series $\mathrm{C} \mathrm{N}^{\circ} 33^{109}$

PARTIAL COMPLIANCE

a. M. C. June 01, 2011, para. 35.

9. APITZ BARBERA ET AL. ("FIRST COURT OF ADMINISTRATIVE DISPUTES") V. VENEZUELA. August 5, 2008. Series C No $182^{110}$.

UNFULFILLED

a. M. C. November 23, 2012, paras. 26-29.

10. BARRIOS ALTOS V. PERU. March 14, 2001. Series C N $75^{111}$.

PARTIAL COMPLIANCE

a. M. C. September 07, 2012, paras. 9, 24 and 35 .

11. LORI BERENSON MEJÍA V. PERU. November 25, 2004. Series C $\mathrm{N}^{\mathrm{o}} 119^{112}$.

a. M. C. June 20, 2012, para. 18 .

COMPLIANCE

12. ANZUALDO-CASTRO V. PERU. September 22, 2009. Series $\mathrm{C} \mathrm{N}^{\mathrm{o}} 202^{113}$.

UNFULFILLED

a. M. C. August 21, 2013, paras. 24-26.

13. CASTANEDA GUTMAN V. MÉXICO. August 6, 2008. Series $\mathrm{C} \mathrm{N}^{\circ} 184^{114}$.

FULL

COMPLIANCE

a. M. C. August 28, 2013, paras. 14, 21-27 and 30.

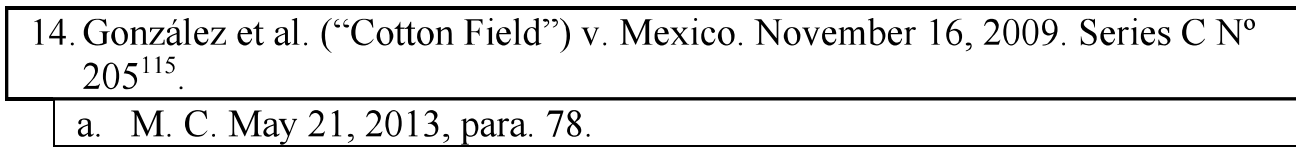

PARTIAL COMPLIANCE

15. ITUANGO MASSACRES V. COLOMBIA. July 1, 2006. Series C No $148^{116}$.

PARTIAL COMPLIANCE

a. M. C. May 21, 2013, paras. 27, 29 and 30 .
16. BLAKE V. GUATEMALA. January 24, 1998. Series C N $36^{117}$.
a. JOINT MONITORING COMPLIANCE OF 11 CASES V. GUATEMALA. M. C. August 21, 2014, para. 17.
b. 12 GUATEMALAN'S CASES V. GUATEMALA. M. C. November 24, 2015, paras. 26 and 142 .

17. "STREET CHILDREN" (VILLAGRÁN-MORALES ET AL.) V. GUATEMALA. November 19, 1999. Series C No $63^{118}$.

a. JOINT MONITORING COMPLIANCE OF 11 CASES V. GUATEMALA. M. C. 21 August 21, 2014, para. 17. 
b. 12 GUATEMALAN'S CASES V. GUATEMALA. M. C. November 24, 2015, paras. 26 and 142 .

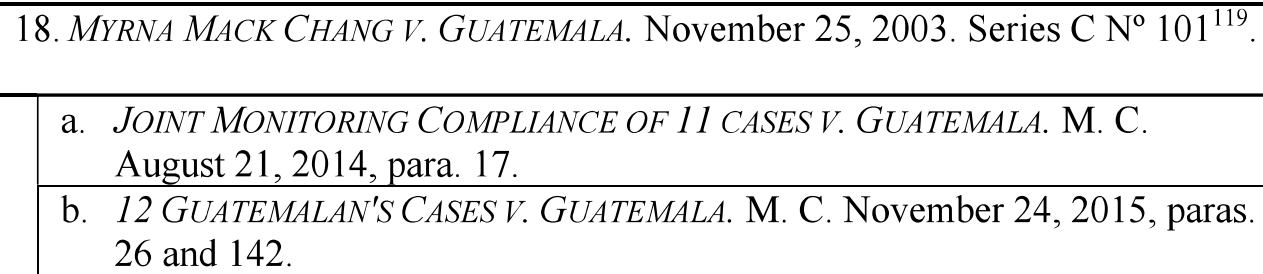
19. MARItZA URRUTIA V. GUATEMALA. November 27, 2003. Series C $\mathrm{N}^{\circ} 103^{120}$.
a. JOINT MONITORING COMPLIANCE OF 11 CASES V. GUATEMALA. M. C. August 21, 2014, para. 17.
b. 12 GUATEMALAN'S CASES V. GUATEMALA. M. C. November 24, 2015, paras. 26 and 142 .

20. PLAN DE SÁNCHEZ MASSACRE V. GUATEMALA. April 29, 2004. Series C N $105^{121}$

UNFULFILLED

a. JOINT MONITORING COMPLIANCE OF II CASES V. GUATEMALA. M. C. August 21, 2014, para. 17.

b. 12 GUATEMALAN'S CASES V. GUATEMALA. M. C. November 24, 2015, paras. 26 and 142 .
21. MOLINA THEISSEN V. GUATEMALA. May 4, 2004. Series C $\mathrm{N}^{\circ} 106^{122}$.
a. JOINT Monitoring COMPLIANCE OF II CASES V. GUATEMALA. M. C. August 21, 2014, para. 17.
b. 12 GUATEMALAN'S CASES V. GUATEMALA. M. C. November 24, 2015, paras. 26 and 142 .

UNFULFILLED

\section{COMPLIANCE}


b. 12 GUATEMALAN'S CASES V. GUATEMALA. M. C. November 24, 2015, paras. 26 and 142 .

25. CHITAY NECH ET AL. V. GUATEMALA. May 25, 2010. Series C $\mathrm{N}^{\circ} 212^{126}$.

UNFULFILLED

a. JOINT MONITORING COMPLIANCE OF 11 CASES V. GUATEMALA. M. C. August 21, 2014, para. 17.

b. I2 GUATEMALAN'S CASES V. GUATEMALA. M. C. November 24, 2015, paras 26 and 142 .

26. "White Van" (Paniagua Morales et al.) v. Guatemala. March 8, 1998. Series $\mathrm{C} \mathrm{N}^{\circ} 37^{127}$.

a. 12 GUATEMALAN'S CASES V. GUATEMALA. M. C. November 24, 2015, paras. 26 and 142 .

UNFULFILLED 